\title{
Hubungan Kepuasan Kerja dengan Turnover Intentions pada Perawat Rumah Sakit Dhuafa
}

\author{
Job Satisfaction Relationship with Turnover Intentions in Dhuafa Hospital Nurses
}

\author{
Inge Mardiana ${ }^{{ }^{*}}$, Aida Vitayala S. Hubeis ${ }^{2}$ dan Nurmala K. Panjaitan ${ }^{3}$
}

${ }^{1}$ Program Magister Manajemen Bisnis Sekolah Pascasarjana IPB

${ }^{2}$ Departemen Komunikasi dan Pengembangan Masyarakat, Fakultas Ekologi Manusia Insitut Pertanian Bogor

Jl. Kamper, Kampus IPB Darmaga, Bogor 16680

\begin{abstract}
ABSTRAK
Kebijakan Pemerintah melalui program Jaminan Kesehatan Nasional (JKN) perlu direspon dengan tetap memberikan pelayanan kesehatan terbaik bagi masyarakat. Pelayanan kesehatan dapat diberikan dengan baik jika jumlah sumber daya manusia (SDM) yang diperlukan seperti perawat terpenuhi secara mutu dan jumlah. Saat ini Rumah Sakit Dhuafa (RS Dhuafa) masih kesulitan memenuhi jumlah tenaga perawat sesuai kebutuhan. Terjadinya tingkat turnover yang cukup tinggi dari perawat yang telah terekrut pada periode Januari-Desember 2013, perlu diketahui faktor penyebabnya, antara lain faktor kepuasan kerja. Secara teori faktor kepuasan kerja menjadi faktor yang dapat memengaruhi kecenderungan dan keputusan karyawan untuk keluar dari tempat kerjanya. Berdasarkan latar belakang tersebut, penelitian dilakukan untuk mengetahui bagaimana hubungan antara kepuasan kerja dan turnover intentions pada perawat. Tujuannya adalah selain dapat menganalisis hubungan kepuasan kerja dengan turnover intentions pada perawat di RS Dhuafa, juga dapat mengetahui faktor ketidakpuasan yang paling berpengaruh terhadap turnover intentions. Jenis penelitian adalah korelasi dengan pendekatan deskriptif dan menguji hipotesis yang telah dirumuskan sebelumnya. Teknik pengambilan data dengan teknik kuesioner dan wawancara, serta teknik analisis data yang digunakan adalah Analisis Partial Least Square (PLS). Hasil penelitian menunjukkan bahwa secara umum perawat RS Dhuafa merasa puas bekerja di RS Dhuafa. Walaupun pembayaran dan kesempatan promosi kurang memberi kepuasan bagi mereka, namun secara umum walaupun para perawat di RS Dhuafa mempunyai faktor yang mengidentifikasi turnover intentions tetapi umumnya mereka masih akan bertahan bekerja di RS Dhuafa.
\end{abstract}

Kata kunci : kepuasan kerja, perawat, rumah sakit, turnover intentions

\section{ABSTRACT}

Government policy through the National Health Insurance program (JKN) needs to be responded to maintain providing the best health services for the community. Best health services can be provided by the fulfillment of the human resources (HR) such as nurse either in the quality and quantity. Currently Dhuafa Hospital (RS Dhuafa) is still difficult to meet the number of nurses requirement. Highly turnover rate of nurses occured in the period January to December 2013. It is clearly important to know the causes, among other factors of job satisfaction. In theory, job satisfaction is one of the factors that may influence the tendency of employee to decide to get out of work. Based on this background, the study was conducted to determine how the relationship between job satisfaction and highly intentions of nurses turnover rate in Dhuafa Hospital. The purpose of this study are to analyze the relationship between job satisfaction and nurses turnover rate in Dhuafa hospital, and also to find out the most dominant factors on turnover intentions. This research is done by statistical methodology using the correlation, descriptive approach and test the hypotheses that have been formulated previously. Data collection will be exercises by questionnaire and interview techniques, and will be analyze using Partial Least Square (PLS). The

\footnotetext{
*) Korespondensi:

RS Rumah Sehat Terpadu; Jl. Raya Parung Bogor Km 42 Kabupaten Bogor; email: inge.bgr@gmail.com
} 
results showed that in general, nurses were satisfied geeting work in Dhuafa hospital, although less of payments and promotion opportunities were insists. Those factors were the trigger of job satisfaction to them. In general, the study conclude that although the nurses turnover in Dhuafa hospital were getting intense but they still have highly survival rate to work in Dhuafa hospital.

Key words: hospital, job satisfaction, nurses, turnover intentions

\section{PENDAHULUAN}

Sejak pemerintah mengeluarkan undangundang tentang Sistem Jaminan Sosial Nasional (SJSN), beberapa program kesehatan telah dijalankan. Salah satu program SJSN adalah program Jaminan Kesehatan Nasional (JKN) yang akan menjamin pesertanya memperoleh manfaat pemeliharaan kesehatan dan perlindungan dalam memenuhi kebutuhan dasar kesehatan. Program JKN mulai digulirkan awal tahun 2014, dan ditargetkan pada tahun 2019 seluruh masyarakat Indonesia menjadi peserta JKN. Program baik dari pemerintah harus direspon dengan baik pula, namu program ini bukan tanpa kendala dan protes, terutama dari rumah sakit kelas D yang menilai tarif paket tindakan yang ditetapkan melalui tarif INACBGs dinilai relatif rendah.

Kebijakan pemerintah tersebut membuat pemilik dan atau pimpinan rumah sakit di seluruh Indonesia mempersiapkan diri dalam mengimplementasikannya pada rumah sakit masing-masing. Begitu pula yang dilakukan oleh pimpinan Rumah Sakit Dhuafa (RS Dhuafa). RS Dhuafa merupakan Rumah Sakit Umum, yang tujuan pendiriannya dikhususkan untuk melayani pengobatan masyarakat miskin dan tidak mampu. Pasien RS Dhuafa berbeda dengan pasien pada umumnya suatu rumah sakit, mereka adalah pasien yang telah terverifikasi oleh tim khusus sebagai orang miskin dan tidak mampu. Sebagai rumah sakit milik masyarakat, karena RS Dhuafa dibangun atas dana zakat, infak, dan sedakhah (ZIS) yang dihimpun oleh Yayasan Pengelola ZISWAF Nasional, maka sebagai rumah sakit publik yang bersifat nirlaba, mengedepankan fungsi sosial dari rumah sakit. Di rumah sakit ini pasien yang berobat tidak melakukan transaksi pembayaran karena biaya pengobatan pasien telah ditanggung oleh donatur melalui ZIS yang terhimpun.

Kebijakan pemerintah di bidang kesehatan melalui Jaminan Kesehatan Nasional (JKN) pada awal tahun 2014, sedikit banyak memengaruhi kebijakan RS Dhuafa, yang tidak boleh menolak pasien peserta JKN terlebih setelah RS Dhuafa menjadi salah satu rumah sakit provider Badan Penyelenggara Jaminan Sosial (BPJS). Peran sebagai provider BPJS diawali karena peserta Jamkesmas yang selama ini dilayani berobat di RS Dhuafa secara otomatis menjadi peserta JKN dengan kategori Penerima Bantuan Iuran (PBI) dari pemerintah. Menjadi pembeda dengan rumah sakit lain, RS Dhuafa yang merupakan rumah sakit kelas $\mathrm{D}$, dapat tetap membiayai pasien yang telah menjadi peserta meskipun dana dari klaim BPJS lebih rendah dari biaya pengobatan yang diterima pasien.

Meskipun RS Dhuafa dikhususkan untuk masyarakat miskin dan tidak mampu, namun RS Dhuafa tetap harus memberikan pelayanan kesehatan yang mengutamakan kepentingan pasien sesuai standar pelayanan rumah sakit sebagaimana diatur dalam undang-undang. Selama pasien dirawat di rumah sakit, pasien berada dibawah pengawasan tenaga kesehatan rumah sakit, mulai dari dokter, perawat, ahli gizi, analis kesehatan dan lain sebagainya. Di antara tenaga kesehatan yang ada di rumah sakit, tenaga kesehatan yang paling intens melayani pasien dalam proses pengobatan dan pemulihan kesehatan pasien adalah tenga perawat, karena perawat mendampingi pasien selama 24 jam. Pada umumnya di rumah sakit, perawat merupakan sumber daya manusia (SDM) dengan jumlah terbesar $( \pm 40 \%)$ dari seluruh SDM rumah sakit, dan menjadi faktor yang memengaruhi mutu pelayanan rumah sakit. Kekurangan tenaga perawat dapat berdampak buruk pada pelayanan rumah sakit, pasien kurang tertangani dengan baik, dan berdampak kelelahan pada tenaga perawat yang ada.

Perkembangan rumah sakit di Indonesia cukup pesat berdasarkan data Kementerian Kesehatan Maret 2013, jumlah rumah sakit mencapai 2.083 buah, naik 6\% dari bulan Mei 2012 yang berjumlah 1.959 buah. Jumlah tenaga perawat sampai dengan Maret 2013 mencapai 220.575 orang. Berdasarkan perhitungan Kementerian Kesehatan jumlah tersebut telah mencukupi, namun secara distribusi belum merata di seluruh Indonesia. Seringkali rumah sakit kekurangan 
tenaga perawat. Hal tersebut terjadi karena minimnya pelamar atau perawat yang telah terekrut keluar atau berhenti dari rumah sakit. Kondisi tersebut dialami oleh banyak rumah sakit di Indonesia termasuk RS Dhuafa. Sejak RS Dhuafa beroperasi dua tahun lalu (2012), masih kesulitan memenuhi jumlah tenaga perawat sesuai kebutuhan yang ideal. Hinggal awal tahun 2014 perbandingan jumlah tempat tidur pasien dan tenaga perawat secara rasio masih sekitar 1 : 1, sedangkan berdasarkan Permenkes nomor 340 tahun 2010 tentang Klasifikasi Rumah Sakit Umum pasal 19 ayat (4), perbandingan tenaga keperawatan dan tempat tidur adalah $2: 3$ dengan kualifikasi tenaga keperawatan sesuai dengan pelayanan di rumah sakit. Kondisi tersebut menunjukkan bahwa RS Dhuafa masih kekurangan perawat. Kekurangan terjadi tidak saja dari kuantitas dan mutu perawat sesuai yang dibutuhkan, permasalahan lainnya adalah terjadi turnover yang cukup tinggi dari perawat-perawat yang telah terekrut. Berdasarkan data yang ada, tingkat turnover perawat selama periode JanuariDesember 2013 sebesar 13\%. Tingkat turnover tersebut dinilai cukup tinggi, karena menurut Gillis dalam Aryanto (2011), keluarnya perawat dari rumah sakit dikatakan normal berkisar antara $5-10 \%$ per tahun, dikatakan tinggi apabila lebih dari $10 \%$.

Pada dasarnya tidak ada rumah sakit yang dapat menghindari terjadinya turnover pegawai, namun jika terjadi turnover yang tinggi dan tidak segera ditekan dikhawatirkan dapat mengganggu pelayanan terhadap pasien, dan menjadi permasalahan bagi rumah sakit secara keseluruhan. Banyak faktor yang memengaruhi terjadinya turnover pegawai, namun umumnya faktor yang menyumbang tingkat turnover pegawai yang tinggi adalah faktor ketidakpuasan karyawan. Padahal kepuasan karyawan dapat membantu dalam memaksimalkan profitabilitas perusahaan dalam jangka panjang melalui empat cara, karena karyawan yang puas cenderung; bekerja dengan mutu yang lebih tinggi, bekerja dengan lebih produktif, bertahan lebih lama dalam perusahaan, dan dapat menciptakan pelanggan yang puas (Kuswadi, 2004).

Timbulnya turnover umumnya diawali dengan adanya turnover intentions (niat untuk keluar) dari karyawan. Faktor kepuasan kerja menjadi faktor yang paling memengaruhi kecenderungan dan keputusan karyawan untuk keluar dari tempat kerjanya. Sebagaimana hasil penelitian Rageb et al. (2013) yang menyatakan bahwa kepuasan kerja memiliki dampak lebih besar terhadap turnover intentions, dibandingkan dengan kinerja pekerjaan atau komitmen organisasi. Berdasarkan latar belakang tersebut, peneliti mencoba menganalisis hubungan kepuasan kerja dengan turnover intentions dari para perawat di RS Dhuafa, selain itu peneliti juga berharap dapat mengetahui faktor ketidakpuasan yang paling berpengaruh terhadap turnover intentions dari perawat di RS Dhuafa.

Tingginya turnover perawat di RS Dhuafa perlu ditelaah permasalahan yang melatarbelakanginya. Faktor kepuasan kerja merupakan faktor yang dapat menimbulkan keinginan berhenti atau tunover intentions dari perawat RS Dhuafa. Berdasarkan latar belakang di atas, maka permasalah dalam penelitian ini adalah bagaimana hubungan kepuasan kerja dengan turnover intentions pada perawat di RS Dhuafa, dan mencoba menggali faktor ketidakpuasan apakah yang paling berpengaruh terhadap turnover intentions dari perawat di RS Dhuafa.

Penelitian ini dilakukan untuk mencoba mengkaji permasalahan yang telah dirumuskan. Tujuan penelitian ini adalah menganalisis hubungan kepuasan kerja dengan turnover intentions perawat di RS Dhuafa, serta dapat mengetahui faktor ketidakpuasan apakah yang paling berpengaruh terhadap turnover intentions dari perawat di RS Dhuafa.

\section{METODOLOGI}

Penelitian ini dilakukan di RS Dhuafa yang berlokasi di daerah Parung Kabupaten Bogor. Penelitian dilakukan dalam dua tahap yaitu tahap persiapan dan pengambilan data sekunder, kemudian dilanjutkan dengan tahap penelitian dan pengambilan data primer. Waktu persiapan hingga penelitian dilakukan sejak bulan Desember 2013 hingga April 2014.

Penelitian didesain sebagai penelitian korelasi (correlational study) dengan menggunakan pendekatan deskriptif. Metode deskriptif bertujuan menjawab pertanyaan penelitian. Penelitian menggunakan beberapa jenis dan sumber data. Jenis dan sumber data yang digunakan dalam penelitian ditunjukkan pada Tabel 1.

Populasi penelitian adalah perawat yang bekerja di RS Dhuafa, dengan jumlah responden enam puluh orang. Responden berasal dari beberapa unit kerja pelayanan kesehatan di 
rumah sakit. Responden dibatasi dengan masa kerja, yaitu perawat yang telah mempunyai masa kerja sekurang-kurangnya enam bulan.

Tabel 1. Jenis dan sumber data

\begin{tabular}{|c|c|c|}
\hline No & Jenis Data & Sumber Data \\
\hline \multirow[t]{5}{*}{1} & Data sekunder & \\
\hline & $\begin{array}{l}\text { Teori yang mendukung } \\
\text { penelitian }\end{array}$ & Studi literatur \\
\hline & Data kepegawaian & Laporan bagian \\
\hline & & kepegawaian \\
\hline & Data rumah sakit & Laporan rumah sakit \\
\hline \multirow[t]{5}{*}{2} & Data primer & \\
\hline & Gambaran umum & Observasi langsung \\
\hline & lokasi penelitian & \\
\hline & $\begin{array}{l}\text { Gambaran umum } \\
\text { perawat }\end{array}$ & $\begin{array}{l}\text { Wawancara atasan } \\
\text { perawat }\end{array}$ \\
\hline & Persepsi perawat & Kuesioner perawat \\
\hline
\end{tabular}

Metode pengambilan data penelitian dilakukan dengan dua tahap, yaitu;

1. Mencari dan mengumpulkan data sekunder..

2. Mengumpulkan data primer dilakukan melalui cara:

a. Kuantitatif dilakukan dengan kuesioner. Setiap butir pertanyaan mempunyai empat pilihan jawaban yang diberi poin dengan skala 1 (sangat tidak setuju atau sangat tidak puas) sampai 4 (sangat setuju atau sangat puas).

b. Kualitatif dilakukan dengan wawancara kepada pejabat yang berwenang di divisi keperawatan.

Untuk lebih memudahkan dalam memahami setiap peubah dari penelitian ini dibuat definisi operasional dan indikatornya (Tabel 2). Data yang memenuhi persyaratan dalam penelitian kemudian dilakukan pengolahan. Analisis deskriptif digunakan untuk menguraikan atau memberikan keterangan-keterangan tentang data yang telah diolah tanpa mengambil kesimpulan.

Metode penelitian yang digunakan adalah: Analisis Partial Least Square (PLS) dengan software smartPLS versi 2.0. Analis PLS bukan saja dapat digunakan untuk mengkonfirmasi teori, tetapi juga digunakan menjelaskan ada atau tidaknya hubungan antara peubah laten. Langkah-langkah analisis menggunakan PLS adalah:

1. Merancang model struktural (inner model)

2. Merancang model pengukuran

3. Mengkonstruksi diagram jalur

4. Konversi diagram jalur ke dalam model persamaan
5. Estimasi

6. Evaluasi goodness-of-fit. Evaluasi goodness-of-fit dibagi dua, yaitu outer model dan inner model. Outer model terdiri dari:

a. Outer model reflektif :

1) Convergent validity: Suatu indikator dinyatakan valid jika nilai loading factor di atas 0,5 terhadap konstruk yang dituju.

2) Discriminant validity: Nilai AVE yang direkomendasikan adalah lebih besar dari 0,50 . Rumus yang dipakai adalah:

$$
A V E=\frac{\sum \lambda_{i}^{2}}{\sum \lambda_{i}^{2}+\sum_{i} \operatorname{var}\left(\varepsilon_{i}\right)}
$$

3) Composite reliability

Nilai batas yang diterima untuk tingkat reliabilitas komposit (oc) adalah $\geq 0,6$, walaupun bukan merupakan standar absolut. Rumus oc adalah:

$$
p c=\frac{\left(\sum \lambda i\right)^{2}}{\left(\sum \lambda i\right)^{2}+\sum_{i} \operatorname{var}\left(\varepsilon_{i}\right)}
$$

Setelah model yang diestimasi memenuhi kriteria outer model, berikutnya dilakukan pengujian goodness of fit untuk inner model.

\begin{tabular}{|c|c|c|}
\hline Peubah & $\begin{array}{c}\text { Definisi } \\
\text { Operasional }\end{array}$ & Indikator \\
\hline $\begin{array}{l}\text { Kepuasan } \\
\text { kerja }\end{array}$ & $\begin{array}{l}\text { Keadaan emosi } \\
\text { seseorang yang } \\
\text { mencermin kan } \\
\text { respon terhadap } \\
\text { kesesuaian antara } \\
\text { harapan dan } \\
\text { kenyataan }\end{array}$ & $\begin{array}{ll}\text { 1. } & \begin{array}{l}\text { Pembayaran } \\
\text { (kepuasan 1); }\end{array} \\
\text { 2. } & \begin{array}{l}\text { Pekerjaan } \\
\text { (kepuasan 2); }\end{array} \\
\text { 3. } & \begin{array}{l}\text { Kesempatan } \\
\text { promosi }\end{array} \\
\text { (kepuasan 3); } & \text { Penyelia } \\
\text { 4. }\end{array}$ \\
\hline $\begin{array}{l}\text { Turnover } \\
\text { Intentions }\end{array}$ & $\begin{array}{l}\text { Kecenderungan } \\
\text { atau niat untuk } \\
\text { berhenti bekerja }\end{array}$ & $\begin{array}{ll}\text { 1. } & \text { Absensi (TI1); } \\
\text { 2. } & \text { Disiplin } \\
\text { kehadiran (TI2); } \\
\text { 3. Kepatuhan tata } \\
\text { tertib (TI3); } \\
\text { 4. Protes pada } \\
\text { atasan (TI4); } \\
\text { 5. Penyelesaian } \\
\text { tugas (TI5); } \\
\text { 6. Mencari } \\
\text { informasi } \\
\text { pekerjaan (TI6); } \\
\text { 7. Berpikir untuk } \\
\text { berhenti (TI7). }\end{array}$ \\
\hline
\end{tabular}

Tabel 2. Definisi operasional 
b. Inner model

a. Inner model diukur dengan menggunakan $Q$-Square predictive relevance.

Rumus Q-Square sebagai berikut:

$$
\mathrm{Q}^{2}=1-\left(1-\mathrm{R}_{1}^{2}\right)\left(1-\mathrm{R}_{2}^{2}\right) \ldots\left(1-\mathrm{R}_{\mathrm{p}}^{2}\right)
$$

Dimana $\mathrm{R}_{1}{ }^{2}, \mathrm{R}_{2}{ }^{2}, \ldots \mathrm{R}^{2}$ adalah $\mathrm{R}$-square peubah endogen dalam model Interpretasi $\mathrm{Q}^{2}$ sama dengan koefisien determinasi total pada analisis jalur (mirip dengan $\mathrm{R}^{2}$ pada regresi).

7. Pengujian Hipotesis (Resampling Bootstraping), Pengujian hipotesis dilakukan berikut :

a. Hipotesis statistik untuk outer model:

1) $\mathrm{H}_{0}: \lambda \mathrm{i}=0$ lawan

2) $\mathrm{H}_{1}: \lambda \mathrm{i} \neq 0$

b. Hipotesis statistik untuk inner model: peubah laten eksogen terhadap endogen:

1) $\mathrm{H}_{0}: \gamma \mathrm{i}=0 \quad$ lawan

2) $\mathrm{H}_{1}: \gamma \mathrm{i} \neq 0$

c. Hipotesis statistik untuk inner model: peubah laten endogen terhadap endogen:

1) $\mathrm{H}_{0}: \beta \mathrm{i}=0 \quad$ lawan

2) $\mathrm{H}_{1}: \beta \mathrm{i} \neq 0$

d. Statistik uji: t-test; $p$-value $\leq 0.05$ (alpha 5 $\%)$; nyata.

e. Outter model signifikan: indikator bersifat valid

f. Inner model nyata: terdapat pengaruh nyata

g. PLS tidak mengasumsikan data berdistribusi normal: menggunakan teknik resampling dengan metode Bootstrap.

Setelah diketahui hubungan antar peubah, selanjutnya dilakukan penilaian indikator dari setiap peubah, untuk mengetahui indikator yang paling memengaruhi. Penilaian dilakukan dengan menghitung jumlah dan mengelompokkannya sehingga diperoleh gambaran pengaruh dari setiap indikator dari peubah penelitian.

\section{HASIL DAN PEMBAHASAN}

Karakteristik dari responden diklasifikasikan berdasarkan jenis kelamin, usia, status marital, pendidikan terakhir, pengalaman kerja, masa kerja, status kepegawaian, dan jabatan.

\section{Jenis Kelamin Responden}

Karakteristik responden berjenis kelamin perempuan lebih banyak (63\%), dibandingkan responden laki-laki (37\%).

\section{Usia Responden}

Secara keseluruhan usia responden relatif muda, dan responden usia di bawah 25 tahun menjadi responden terbanyak, yaitu $63 \%$. Responden yang berusia antara 26 tahun hingga 30 tahun sebanyak 33\%, sedangkan responden yang berusia antara 31 tahun hingga 35 tahun, dan responden yang berusia di atas 35 tahun masing-masing hanya sebanyak $2 \%$. Gambar 1 menunjukkan secara grafik besaran persentase berdasarkan usia dari responden pada penelitian ini.

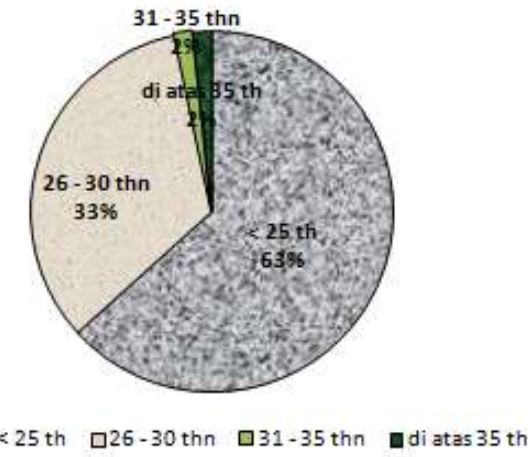

Gambar 1. Grafik persentase responden berdasarkan usia

\section{Status Marital Responden}

Sebagaimana data usia responden yang mayoritas berusia muda (di bawah 25 tahun), hal tersebut berkaitan pula dengan mayoritas status marital responden. Status marital responden pada penelitian ini yang terbanyak adalah responden yang belum menikah sebanyak $68 \%$, sedangkan yang telah menikah sebanyak $32 \%$, dan tidak ada responden yang mempunyai status marital duda atau janda.

\section{Pendidikan Responden}

Saat ini sesuai ketentuan Kementerian Kesehatan bahwa standar minimal tenaga di keperawatan adalah D3, hal tersebut tergambar dari karakteristik pendidikan responden. Karakteristik responden didominasi oleh respoden berpendidikan D3 yaitu 97\%, sedangkan responden yang berpendidikan S1 hanya 3\%. Tidak ada responden yang berpendidikan $\mathrm{S} 2$.

\section{Pengalaman Bekerja Responden}

Berdasarkan data demografi sebelumnya, responden mayoritas berusia muda, berpendidikan D3, dan belum mempunyai banyak pengalaman bekerja. Hal tersebut berdasarkan data bahwa responden yang mempunyai pengalaman bekerja kurang dari 1 tahun sebanyak 48\%, 
sedangkan yang mengaku telah mempunyai pengalaman bekerja 1-3 tahun sebanyak 52\%. Tidak ada satupun responden yang mempunyai pengalaman bekerja lebih dari 3 tahun.

\section{Masa Kerja Responden}

Pada tahun 2014 RS Dhuafa baru beroperasi dua tahun, sehingga masa kerja dari para karyawan termasuk para perawatnya masih banyak yang baru mempunyai masa kerja di bawah dua tahun. Namun pada umumnya suatu rumah sakit akan merekrut pegawai sebelum rumah sakit tersebut dinyatakan beroperasional, sehingga dimungkinkan ada karyawannya yang mempunyai masa kerja lebih lama daripada masa operasi rumah sakit itu sendiri. Berdasarkan hasil pengumpulan data diperoleh hasil bahwa responden yang terbanyak adalah responden yang telah memiliki masa kerja antara 1 sampai dengan 2 tahun lebih banyak (63\%) dibandingkan responden yang mempunyai masa kerja antara 6 bulan sampai dengan 11 bulan (34\%). Responden yang telah bekerja lebih dari dua tahun hanya 3 persen, yaitu karyawan yang telah terekuit sejak awal rumah sakit akan beroperasi. Gambar 2 menunjukkan secara grafik besaran persentase berdasarkan jenis kelamin dari responden pada penelitian ini.

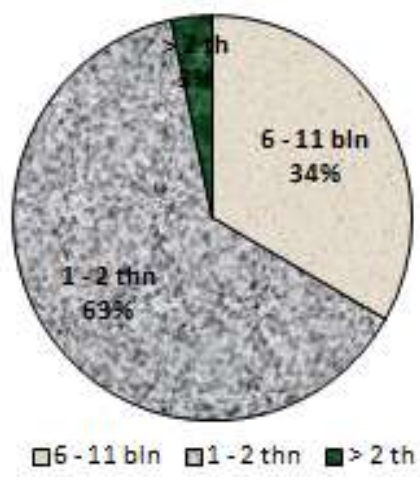

Gambar 2. Grafik persentase responden berdasarkan masa kerja

\section{Status Kepegawaian}

Seorang karyawan diangkat menjadi karyawan tetap jika telah mempunyai masa kerja 2 tahun. Operasi RS Dhuafa relatif baru, sehingga secara karakteristik responden yang ada juga umumnya belum berstatus karyawan tetap. Hal tersebut dapat dilihat dari jumlah persentase responden yang belum menjadi karyawan tetap lebih banyak (87\%), daripada karyawan yang telah berstatus karyawan tetap (13\%).

\section{Jabatan Responden}

Mengingat keperawatan merupakan suatu bagian yang menjadi ujung tombak kegiatan rumah sakit, dan mempunyai jumlah sumber daya manusia terbanyak dibanding bagian atau unit lainnya, maka diperlukan jabatan-jabatan tertentu untuk memudahkan koordinasi dan rentang kendali yang terlalu jauh. Karakteristik responden berdasarkan jabatan di keperawatan di kelompokkan dalam tiga kelompok. Responden dengan jabatan sebagai perawat pelaksana klinik sebanyak 78 persen. Responden dengan jabatan sebagai penanggungjawab (pj) shift sebanyak 20 persen, sedangkan responden dengan jabatan kepala ruangan (karu) sebanyak 2\%. Gambar 8 menunjukkan secara grafik besaran persentase berdasarkan jabatan dari responden pada penelitian ini.

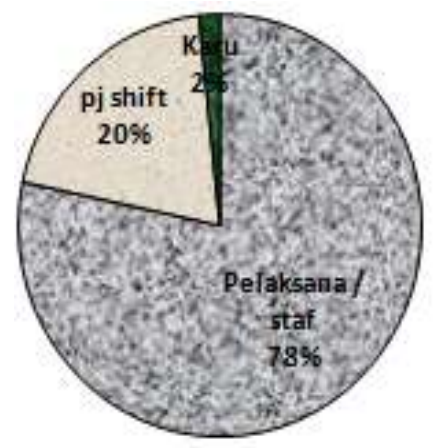

$$
\text { 口Pelaksana/staf } \square p j \text { shift GKaru }
$$

Gambar 3. Grafik persentase responden berdasarkan jabatan

\section{Output Smart PLS}

Data kuesioner yang telah dikumpulkan kemudian diolah dengan metode analistik smartPLS. Pengolahan dengan metode smartPLS dilakukan dengan 2 tahap.

\section{Tahap I}

Pada Tahap I dilakukan pengolahan data sehingga diperoleh diagram jalur persamaan struktural PLS dengan software smartPLS. Pada penelitian ini terdiri dari konstruk kepuasan kerja dan turnover intentions. Setiap konstruk diukur oleh beberapa indikator. Konstruk kepuasan kerja diukur dengan 5 indikator yaitu pembayaran (kepuasan1), pekerjaan (kepuasan2), kesempatan promosi (kepuasan3), atasan (kepuasan4), dan rekan kerja (kepuasan5). Konstruk turnover intentions diukur dengan 7 indikator, yaitu absensi (TI1), keterlambatan (TI2), kepatuhan tata tertib (TI3), protes pada atasan (TI4), penyelesaian tugas 
(TI5), mencari informasi kerja (TI6), dan berpikir berhenti (TI7). Arah panah antara konstruk laten dengan indikator terlihat menuju indikator, hal ini menunjukkan bahwa penelitian ini menggunakan indikator refleksif yang relatif sesuai untuk mengukur persepsi perawat RS Dhuafa. Selain model struktural diperoleh nilai loading factor dari data yang telah diolah.

Hasil output Tahap I, diperoleh diagram jalur persamaan struktural PLS dan nilai loading factor. Diagram persamaan struktural dan nilai loading factor dari data yang telah diolah dalam penelitian ini ditampilkan pada Gambar 4.

Hasil data model ouput dari masing-masing peubah laten pada Tahap I selanjutnya akan dilakukan evaluasi model. Pada hasil Tahap I pada peubah kepuasan kerja yaitu kepuasan5, rekan kerja, dan peubah turnover intentions yaitu absensi (TI1), kedisiplinan kehadiran (TI2), kepatuhan tata tertib (TI3), protes pada atasan (TI4), dan penyelesaian tugas (TI5) mempunyai data output $<0,5$.

\section{Tahap II}

\section{Evaluasi Model Pengukuran (Outer Model) Pengujian Validitas}

Pada penelitian ini dilakukan pengujian validitas dan reliabilitas pada masing-masing peubah laten yaitu peubah kepuasan kerja dan turnover intentions dengan menggunakan bantuan software smartPLS versi 2,0. Pengujian validitas untuk indikator reflektif menggunakan korelasi antara skor item dengan skor konstruknya. Ukuran refleksif individual dikatakan valid jika memiliki nilai loading dengan peubah laten yang ingin diukur $\geq 0.5$, jika salah satu indikator memiliki nilai loading $<0.5$, maka indikator tersebut harus dibuang (didrop), karena akan mengindikasikan bahwa indikator tidak cukup baik untuk mengukur peubah laten secara tepat.

Hasil output diagram jalur persamaan struktural pada PLS dengan menggunakan software SmartPLS versi 2.0 yang telah diperoleh pada Tahap I dilihat nilai loading factor-nya. Hasil pengolahan, disimpulkan bahwa hubungan peubah indikator kepuasan 1, kepuasan 2, kepuasan 3, kepuasan 4, dengan konstruk kepuasan, hubungan peubah indikator TI6 dan TI7 dengan konstruk turnover intentions, masing-masing memiliki nilai loading $\geq 0,5$, dan memiliki nilai Tstatistik $>1,96$ pada taraf signifikansi $\alpha=0,05$. Output hubungan peubah indikator kepuasan 5 dengan konstruk kepuasan, hubungan peubah indikator TI1, TI2, TI3, TI4 dan TI5 dengan konstruk turnover intentions, masing-masing memiliki nilai loading factor $<0,5$, maka indikatorindikator tersebut harus dibuang (didrop).

Hasil outer model Tahap II setelah beberapa indikator yang tidak memenuhi kriteria dibuang, digambarkan dalam diagram. Diagram jalur persamaan struktural dan nilai loading factor Tahap II dapat dilihat pada Gambar 5.

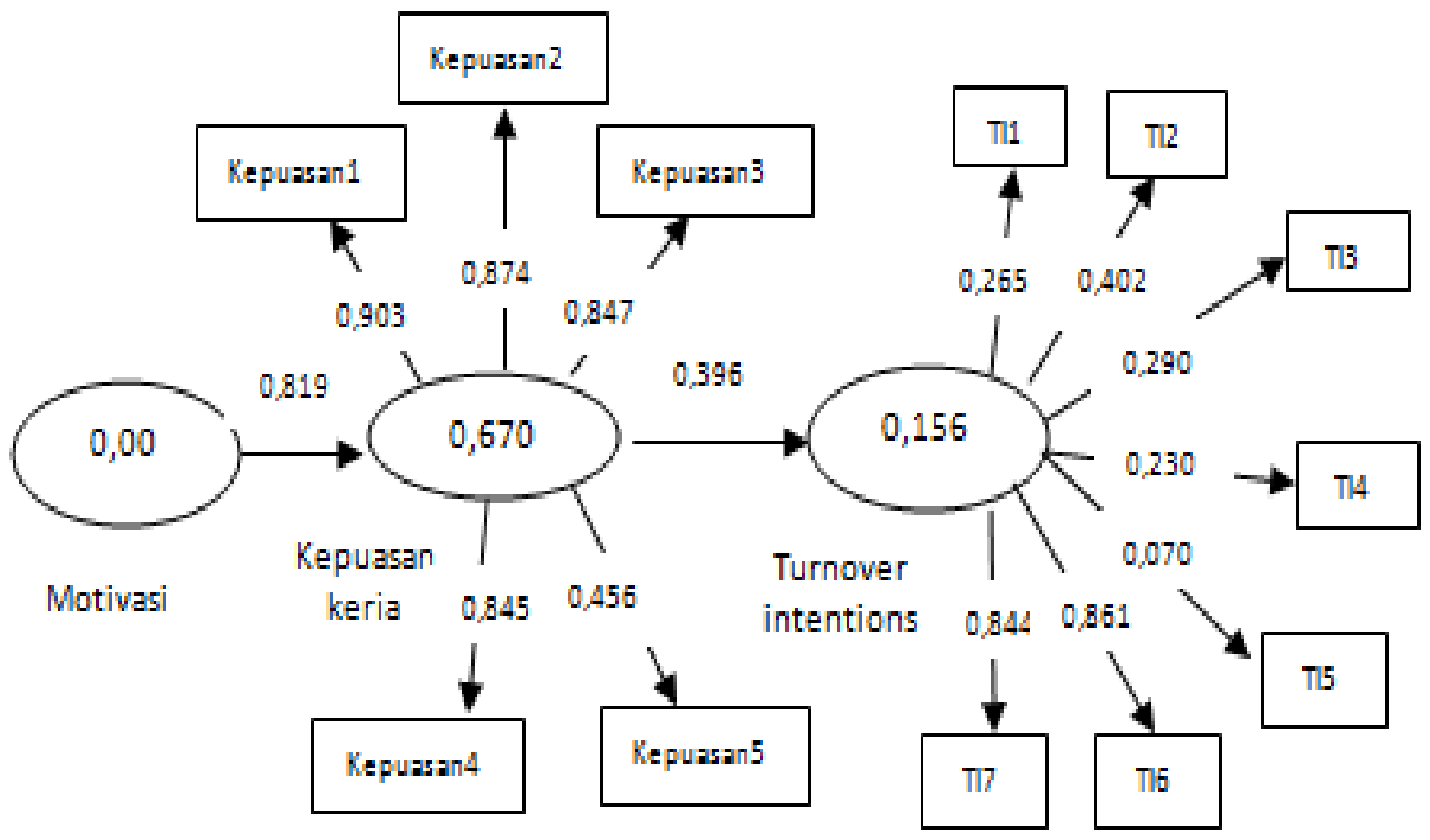

Gambar 4. Diagram jalur persamaan struktural PLS dengan software smartPLSTahap I 

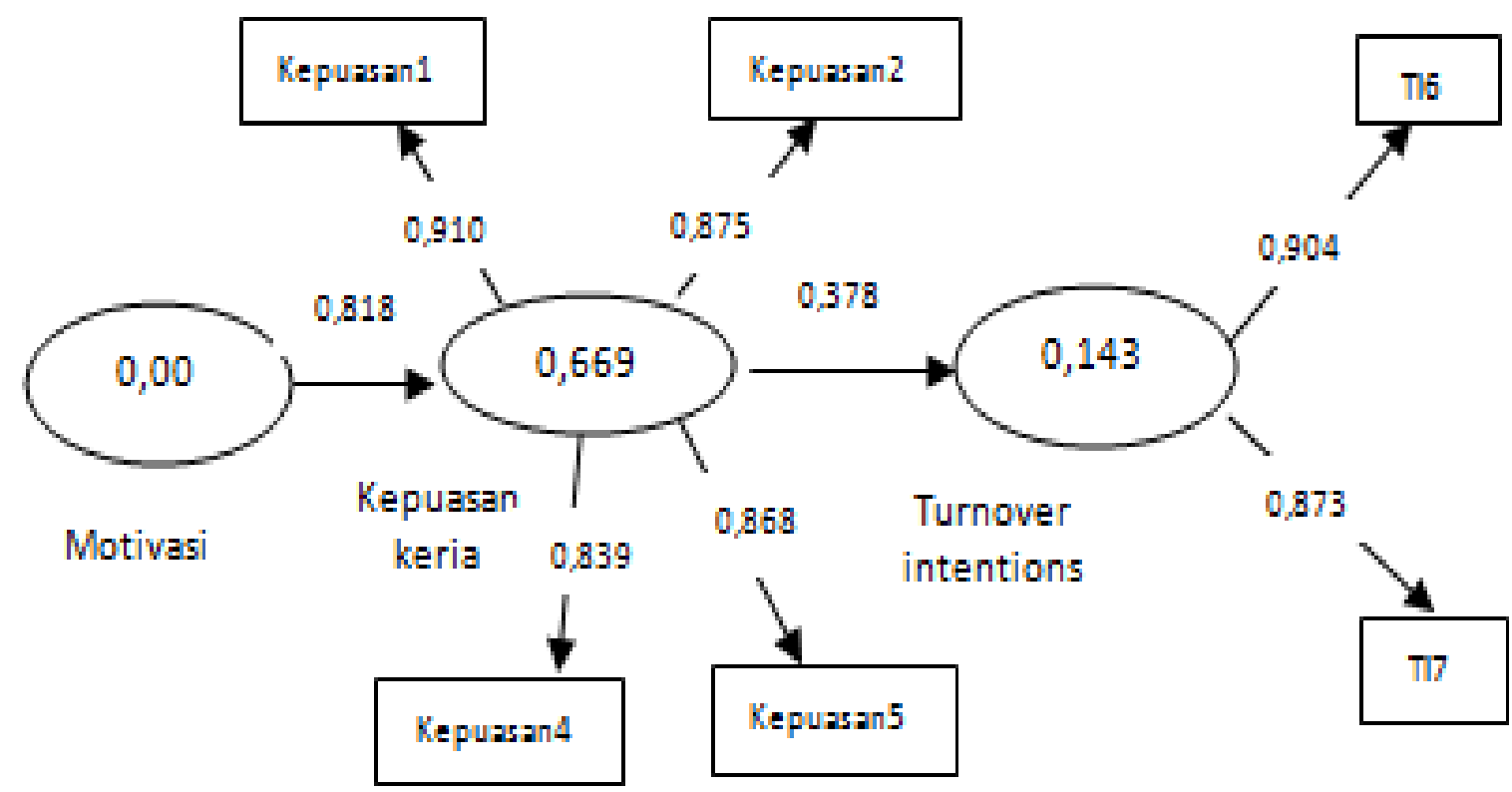

Gambar 5. Diagram jalur persamaan struktural PLS dengan software Smart PLS Tahap II (modifikasi)

Langkah selanjutnya adalah menguji discriminant validity. Metode yang digunakan untuk mengukur nilai discriminant validity dalam penelitian ini adalah dengan melihat nilai Average Variance Extracted (AVE), nilai AVE harus > 0.50. Nilai AVE dapat dilihat pada Tabel 3.

Tabel 3. Average variance extracted (AVE)

\begin{tabular}{lc}
\hline Konstruk & AVE \\
\hline Kepuasan kerja & 0,762704 \\
Turnover Intentions & 0,788965 \\
\hline
\end{tabular}

Pada Tabel 3 terlihat bahwa nilai AVE untuk semua konstruk yang terdapat pada model penelitian ini $>0,50$, sehingga indikator tersebut memenuhi discriminant validity.

\section{Uji Reliabilitas}

Pada penelitian ini suatu peubah dikatakan cukup reliabilitas bila peubah tersebut mempunyai nilai construc reliability lebih besar dari 0,6. Pada Tabel 4 dapat dilihat semua nilai composite reliability untuk semua konstruk adalah di atas 0,7 . Nilai composite reliability yang terendah adalah 0,882 pada konstruk turnover intentions.

Tabel 4. Pengujian Reliabilitas

\begin{tabular}{lcc}
\hline \multicolumn{1}{c}{ Konstruk } & $\begin{array}{c}\text { Composite } \\
\text { Reliability }\end{array}$ & Keterangan \\
\hline $\begin{array}{l}\text { Kepuasan } \\
\text { kerja } \\
\text { Turnover } \\
\text { intentions }\end{array}$ & 0,928 & Reliabele \\
\hline
\end{tabular}

Berdasarkan hasil Tabel 4, peubah kepuasan kerja dan turnover intentions memiliki nilai AVE $>0,5$ dan composite reliability $\geq 0,7$ maka dapat disimpulkan bahwa indikator-indikator yang digunakan pada penelitian ini mempunyai reabilitas yang cukup baik atau mampu untuk mengukur konstruknya.

\section{Evaluasi Model Struktural (Inner Model)}

Model struktural dapat dievaluasi dengan melihat nilai R-square pada konstruk dependen atau peubah endogen dan koefisien parameter jalur (path coeficient parameter). Batas nilai tstatistik untuk menolak dan menerima hipotesis yang diajukan adalah 1,96. Diagram nilai tstatistik atau t-hitung hubungan antar peubah berdasarkan output smartPLS versi 2,0 dapat dilihat pada Gambar 6.

\section{Hubungan Kepuasan Kerja dengan Turnover Intentions pada Perawat RS Dhuafa}

Kepuasan kerja dihipotesiskan mempunyai hubungan dengan turnover intentions pada perawat di RS Dhuafa. Hasil uji signifikansi hubungan antar peubah tersebut dapat dilihat pada Tabel 5. Berikut hipotesis dalam penelitian ini adalah:

$\mathrm{H}_{0}$ : Tidak ada hubungan nyata kepuasan kerja dengan turnover intentions pada perawat di RS Dhuafa.

$\mathrm{H}_{1}$ : Ada hubungan nyata kepuasan kerja dengan turnover intentions pada perawat di RS Dhuafa. 


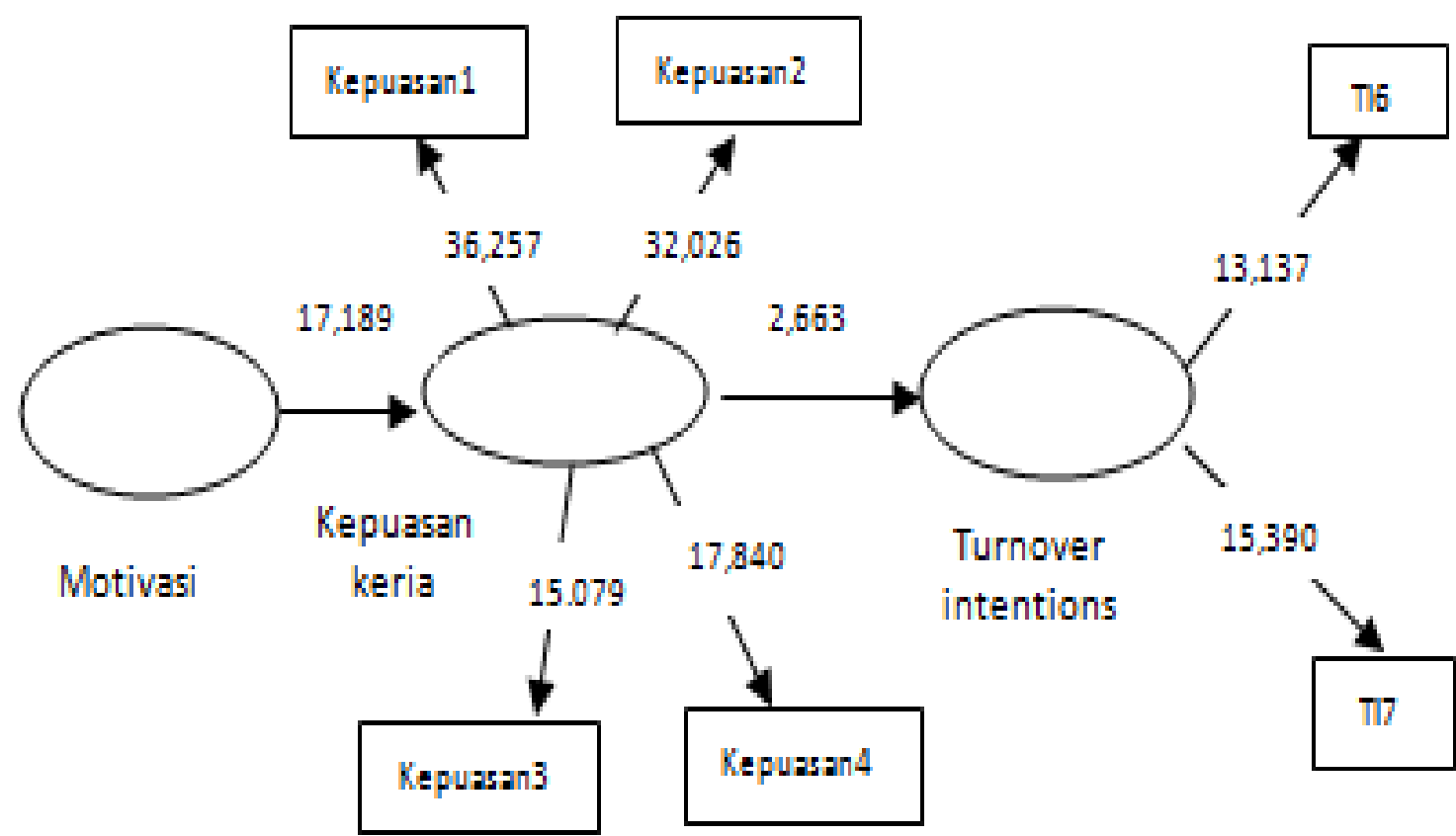

Gambar 6. Diagram nilai t-statistik hubungan antar peubah

Tabel 5. Hubungan kepuasan kerja dan turnover intentions

\begin{tabular}{lcccc}
\hline $\begin{array}{l}\text { Hubungan } \\
\text { Kausalitas }\end{array}$ & $\begin{array}{c}\text { Koefisien } \\
\text { Parameter }\end{array}$ & $\begin{array}{c}\text { Standard } \\
\text { Error } \\
\text { (STERR) }\end{array}$ & $\begin{array}{c}\text { T- } \\
\text { statistik }\end{array}$ & $\begin{array}{c}\mathrm{R} \\
\text { Square }\end{array}$ \\
\hline $\begin{array}{l}\text { Kepuasan } \\
\downarrow\end{array}$ & 0.3783 & 0.1421 & 2.6629 & $14.31 \%$ \\
$\begin{array}{l}\text { Turnover } \\
\text { intentions }\end{array}$ & & & & \\
\hline
\end{tabular}

Interpretasi hasil uji hipotesis berdasarkan data pada Tabel 5 diketahui koefisien hubungan kepuasan dengan turnover intentions sebesar 0.3783 dengan thitung 2.6629 lebih besar dari tabel $(1,96)$, maka $\mathrm{H}_{0}$ dalam penelitian ini ditolak dan $\mathrm{H}_{1}$ yang menyatakan ada hubungan nyata antara kepuasan kerja dengan turnover intentions diterima. Nilai koefisien positif dapat diinterpretasikan semakin tinggi tingkat kepuasan seseorang maka akan membuat orang tersebut semakin tidak ingin meninggalkan pekerjaan atau resign dari rumah sakit. Hasil penelitian ini sesuai dengan penelitian Sijabat (2011), Yuliasia et al. (2012), Rahmawati (2013), dan Nugraha (2014), yang menyimpulkan bahwa kepuasan kerja berpengaruh positif dan signifikan terhadap turnover intentions.

\section{Penilaian Indikator Peubah Penelitian}

Data jawaban responden dari pernyataan yang diajukan dalam kuesioner dikelompokkan dan dihitung total nilai dari setiap indikator masing-masing peubah. Penilaian dari setiap indikator dikelompokkan, dan dilakukan analisa terhadap peubah kepuasan kerja, dan turnover intentions. Hasil penilaian ini untuk menggali indikator yang memengaruhi dari peubah yang diteliti untuk menjawab tujuan penelitian ini.

\section{Penilaian Indikator dari Kepuasan Kerja}

Peubah kepuasan kerja menggunakan lima indikator, yaitu pembayaran, pekerjaan, kesempatan promosi, penyelia atau atasan, dan rekan kerja. Pada kuesioner, masing-masing indikator menggunakan empat pernyataan, sehingga untuk peubah kepuasan kerja seluruhnya ada dua puluh pernyataan. Setiap pernyataan diberi empat jawaban yang diberi nilai 1-4. Sehingga nilai tertinggi dari setiap indikator peubah kepuasan kerja adalah 16. Selanjutnya nilai total jawaban indikator dikelompokkan dalam dua kelompok, yaitu kelompok satu adalah kelompok dengan nilai total jawaban 1-8, dan kelompok dua adalah kelompok dengan nilai total jawaban 9-16, Kelompok satu merupakan kelompok responden yang tidak puas terhadap indikator tersebut, sedangkan kelompok dua adalah kelompok responden yang puas terhadap indikator tersebut. Hasil perhitungan jumlah dan persentase responden setiap indikator dari peubah kepuasan kerja dapat dilihat pada Tabel 6.

Berdasarkan Tabel 6 dapat diketahui bahwa responden menilai beberapa indikator kepuasan kerja yang diukur ada yang memuaskan, namun ada pula yang tidak memuaskan mereka. Terdapat 95\% responden yang menyatakan indikator rekan kerja merupakan indikator yang 
memberi kepuasan kerja, dan merupakan indikator kepuasan kerja tertinggi. Hal tersebut karena faktor usia yang relatif muda dan sebaya membuatnya nyaman dalam berinteraksi dalam bekerja maupun bersosialisasi. Hal tersebut juga menunjukkan hubungan kerja di antara perawat maupun karyawan lain berjalan harmonis dan terjalin kerjasama yang baik. Responden yang merasa puas terhadap pekerjaan terdapat $72 \%$ responden. Karyawan merasa puas terhadap pekerjaan sebagai perawat. Hal tersebut dimungkinkan karena terdapat kesesuaian antara profesi mereka sebagai perawat dengan latar belakang pendidikan mereka dari Diploma Tiga Keperawatan. Kesesuaian pendidikan membuat mereka mengetahui pekerjaan, tanggungjawab yang harus dilakukan, sehingga membuat mereka puas terhadap pekerjaannya sebagai perawat. Indikator penyelia atau atasan tidak terlalu memberi kepuasan bagi responden hanya $62 \%$. Usia responden dengan atasan tidak terlalu jauh dapat menyenangkan atau juga sebaliknya.

Tabel 6. Hasil perhitungan jumlah dan persentase indikator dari kepuasan kerja

\begin{tabular}{|c|c|c|c|c|c|c|c|}
\hline \multirow{2}{*}{\multicolumn{2}{|c|}{$\begin{array}{c}\text { Indikator } \\
\text { Kepuasan kerja }\end{array}$}} & \multicolumn{2}{|c|}{ Tidak Puas } & \multicolumn{2}{|c|}{ Puas } & \multicolumn{2}{|c|}{ Total } \\
\hline & & $1-8$ & $\%$ & $9-16$ & $\%$ & $\mathrm{~N}$ & $\%$ \\
\hline \multirow{3}{*}{ Pembayaran } & K1 & \multirow{3}{*}{29} & \multirow{3}{*}{48} & \multirow{3}{*}{31} & \multirow{3}{*}{52} & \multirow{3}{*}{60} & \multirow{3}{*}{100} \\
\hline & $\begin{array}{l}\text { K2 } \\
\text { K3 }\end{array}$ & & & & & & \\
\hline & K4 & & & & & & \\
\hline \multirow{4}{*}{ Pekerjaan } & K5 & \multirow{4}{*}{17} & \multirow{4}{*}{28} & \multirow{4}{*}{43} & \multirow{4}{*}{72} & \multirow{4}{*}{60} & \multirow{4}{*}{100} \\
\hline & K6 & & & & & & \\
\hline & K7 & & & & & & \\
\hline & K8 & & & & & & \\
\hline \multirow{4}{*}{$\begin{array}{l}\text { Kesempatan } \\
\text { Promosi }\end{array}$} & K9 & \multirow{4}{*}{35} & \multirow{4}{*}{58} & \multirow{4}{*}{25} & \multirow{4}{*}{42} & \multirow{4}{*}{60} & \multirow{4}{*}{100} \\
\hline & K10 & & & & & & \\
\hline & K11 & & & & & & \\
\hline & K12 & & & & & & \\
\hline \multirow{4}{*}{ Atasan } & K13 & \multirow{4}{*}{23} & \multirow{4}{*}{38} & \multirow{4}{*}{37} & \multirow{4}{*}{62} & \multirow{4}{*}{60} & \multirow{4}{*}{100} \\
\hline & K14 & & & & & & \\
\hline & K15 & & & & & & \\
\hline & K16 & & & & & & \\
\hline \multirow{4}{*}{$\begin{array}{l}\text { Rekan } \\
\text { Kerja }\end{array}$} & K17 & \multirow{4}{*}{3} & \multirow{4}{*}{5} & & & & \\
\hline & K18 & & & & & & 100 \\
\hline & K19 & & & 57 & 95 & 60 & 100 \\
\hline & K20 & & & & & & \\
\hline
\end{tabular}

Terdapat indikator yang hasilnya cukup menarik yaitu indikator pembayaran. Selisih antara kepuasan dan ketidakpuasan sangat tipis. Responden yang merasa puas terdapat 52\% responden, sedangkan yang merasa tidak puas terdapat $48 \%$ responden. Responden yang merasa puas mungkin karena sebelumnya mereka menerima gaji yang besarnya didasarkan pada standar Kebutuhan Hidup Layak (KHL) Kabupaten
Bogor, dan pada saat kuesioner diberikan gaji mereka sudah ada peningkatan disesuaikan dengan standar Upah Minimum Kota/Kabupaten Bogor yang berlaku. Selisih standar KHL dan UMK cukup besar, sehingga perubahan gaji dari KHL ke UMK dimungkinkan meningkatkan kepuasan kerja mereka. Selain itu bagi mayoritas responden, RS Dhuafa merupakan tempat kerja pertama sehingga penerimaan saat ini masih mencukupi kebutuhan dirinya sendiri. Bagi responden yang tidak puas terutama bagi mereka yang telah berkeluarga, atau pernah bekerja di rumah sakit lain sehingga membandingkan besaran atau jenis penghasilan yang diterima. Hal tersebut sesuai dengan masukan dari atasan responden bahwa ada ketidakpuasan atas pendapatan yang mereka terima dari beberapa perawat membandingkan dengan tempat kerja lainnya.

Indikator yang memberikan kepuasan terendah adalah kesempatan promosi, karena hanya $42 \%$ responden yang merasa puas. Ketidakpuasan dalam kesempatan promosi terjadi karena keterbatasan formasi jabatan struktural bagi perawat. Jumlah perawat merupakan jumlah karyawan terbanyak di rumah sakit, namun jabatan struktural bagi perawat sedikit, sehingga peluang promosi untuk jabatan struktural bagi mereka relatif kecil.

Beberapa indikator kepuasan kerja perawat RS Dhuafa harus diperbaiki dan ditingkatkan, dan indikator yang sudah baik perlu dipertahankan atau bahkan ditingkatkan, agar kepuasan karyawan khususnya perawat meningkat. Pembayaran, pekerjaan, kesempatan promosi, atasan dan rekan kerja merupakan lima dimensi atau indikator kepuasan kerja yang penting bagi karyawan dalam suatu organisasi termasuk rumah sakit, dan telah banyak dilakukan penelitian terhadap indikator-indikator tersebut. Gibson et al. (1996), menyatakan bahwa dalam beberapa studi, lima dimensi kepuasan kerja telah diukur dengan Indeks Diskripsi Kerja (JDI-Job Descriptive Index).

\section{Penilaian Indikator dari Turnover Intentions}

Peubah turnover intentions menggunakan tujuh indikator, yaitu absensi, kedisiplinan kehadiran, kepatuhan tata tertib, protes pada atasan, penyelesaian tugas, mencari informasi kerja, dan berpikir berhenti kerja. Pada kuesioner setiap indikator menggunakan satu pernyataan, sehingga untuk peubah turnover intentions ada tujuh pernyataan. Setiap pernyataan diberi empat jawaban yang diberi nilai 1-4. Sehingga nilai 
tertinggi dari setiap indikator peubah kepuasan kerja adalah 4. Selanjutnya nilai total jawaban indikator dikelompokkan dalam tiga kelompok, yaitu kelompok satu adalah kelompok dengan nilai total jawaban 1, kelompok dua adalah kelompok dengan nilai total jawaban 2 dan 3, dan kelompok tiga adalah kelompok dengan nilai total jawaban 4. Kelompok satu merupakan kelompok responden yang sering melakukan indikator yang diukur, kelompok dua adalah kelompok responden yang kadang atau pernah melakukan indikator yang diukur, dan kelompok ketiga adalah kelompok responden yang tidak pernah melakukan indikator yang diukur. Hasil perhitungan jumlah dan persentase responden setiap indikator dari peubah turnover intentions dapat dilihat pada Tabel 7.

Berdasarkan Tabel 7 dapat diketahui bahwa hampir semua indikator dari turnover intentions pernah dilakukan oleh responden berkisar 5\%$75 \%$ responden. Namun dari segi tingkat "sering" dari semua indikator relatif rendah antara $0 \%-3 \%$. Indikator absensi diukur dari tingkat ijin atau tidak masuk kerja, diperoleh hasil sebanyak $68 \%$ responden menyatakan pernah ijin. Begitu pula dengan keterlambatan, sebanyak $75 \%$ responden menyatakan pernah terlambat datang bekerja. Berdasarkan data dari bagian kepegawaian RS Dhuafa, untuk kehadiran dan keterlambatan di bagian keperawatan masih dalam batas yang ditolerir peraturan rumah sakit, seperti ketidakhadiran rata-rata tidak lebih dari satu kali dalam tiga bulan dan umumnya karena alasan sakit. Data keterlambatan di bagian kepegawaian tercatat rata-rata tidak lebih dari empat kali dalam sebulan. Hal tersebut mungkin karena adanya peraturan yang memberi sanksi bagi yang tidak bekerja atau datang terlambat, berupa pemotongan tunjangan sesuai ketentuan.

Pelanggaran terhadap peraturan rumah sakit pernah dilakukan oleh $55 \%$ responden. Namun pelanggaran tersebut masih dalam bentuk pelanggaran kecil yang tidak menimbulkan catatan di bagian kepegawaian. Hal tersebut dibuktikan dengan tidak ada perawat yang sampai diberi surat teguran atau peringatan tertulis akibat pelanggaran yang dilakukan. Komplain atau protes pada atasan relatif rendah, pernah dilakukan oleh $38 \%$ responden, dan 3\% responden yang sering protes. Menurut informasi dari atasannya di bagian keperawatan, protes pernah dilakukan oleh beberapa perawat tapi masih dalam batas kewajaran. Komplain yang dilakukan lebih banyak mengenai gaji dan pengaturan jam kerja, dikarenakan kurangnya tenaga perawat, namun sejauh ini mereka menilai masih dapat menangani keluhan atau protes yang disampaikan.

Indikator turnover intentions yang cukup tinggi dilakukan responden adalah mencari informasi kerja pernah dilakukan oleh $67 \%$ responden, hal tersebut dilakukan karena kemudahan untuk mencari informasi melalui media telekomunikasi maupun media elektronik lainnya. Mereka mempunyai teman, perawat yang ada umumnya menguasai teknologi internet, mempunyai alat komunikasi seperti handphone, sehingga sangat memudahkan berkomunikasi dengan teman untuk mencari informasi secara cepat dan mudah. Responden yang pernah berpikir untuk berhenti juga cukup tinggi yaitu sebanyak $57 \%$ responden, dan ada juga responden yang sering berpikir untuk berhenti namun hanya $2 \%$ responden. Seorang karyawan yang tidak puas dimungkinkan mempunyai keinginan berhenti bekerja tetapi

Tabel 7. Hasil perhitungan jumlah dan persentase setiap indikator turnover intentions

\begin{tabular}{lccccccccc}
\hline \multicolumn{1}{c}{\begin{tabular}{c} 
Indikator \\
\multicolumn{1}{c}{ Turnover Intentions }
\end{tabular}} & \multicolumn{2}{c}{ Sering } & \multicolumn{2}{c}{$\begin{array}{c}\text { Kadang/ } \\
\text { Pernah }\end{array}$} & \multicolumn{2}{c}{$\begin{array}{c}\text { Tidak } \\
\text { Pernah }\end{array}$} & \multicolumn{2}{c}{ Total } \\
\cline { 3 - 9 } & & 1 & $\%$ & 2 dan 3 & $\%$ & 4 & $\%$ & N & $\%$ \\
\hline Tidak masuk kerja /ijin (absensi) & TI1 & 0 & 0 & 41 & 68 & 19 & 32 & 60 & 100 \\
Keterlambatan kehadiran & TI2 & 0 & 0 & 45 & 75 & 15 & 25 & 60 & 100 \\
Melanggar tata tertib & TI3 & 0 & 0 & 33 & 55 & 27 & 45 & 60 & 100 \\
Protes atasan & TI4 & 2 & 3 & 23 & 38 & 35 & 58 & 60 & 100 \\
Melalaikan penyelesaian tugas & TI5 & 1 & 2 & 3 & 5 & 56 & 93 & 60 & 100 \\
Mencari info kerja & TI6 & 0 & 0 & 40 & 67 & 20 & 33 & 60 & 100 \\
Berpikir berhenti & TI7 & 1 & 2 & 34 & 57 & 25 & 42 & 60 & 100 \\
\hline
\end{tabular}


tetap bertahan. Turnover intentions dapat ditandai dengan beberapa perilaku antara lain mangkir, Mobley (1986) mengutip pernyataan Porter dan Steer 1973; Staw dan Oldham 1978; Streers dan Mowday 1981, bahwa seseorang ingin meninggalkan pekerjaannya, tetapi tidak dapat berbuat begitu (karena kurangnya peluang dan kesempatan lainnya, kendala keluarga, dan sebagainya), mereka dapat melakukan berbagai bentuk penguduran diri lain, seperti misalnya, mangkir, lesu dalam pekerjaan, sabotase, dan memberikan kualitas pekerjaan yang rendah.

\section{KESIMPULAN}

Berdasarkan hasil yang diperoleh dan pembahasan yang telah dilakukan, dapat disimpulkan bahwa kepuasan kerja mempunyai hubungan yang nyata dengan timbulnya turnover intentions pada perawat di RS Dhuafa. Secara umum perawat RS Dhuafa merasa puas bekerja di RS Dhuafa. Walaupun pembayaran dan kesempatan promosi kurang memberi kepuasan bagi mereka, namun secara umum walaupun para perawat di RS Dhuafa mempunyai faktor yang mengidentifikasi turnover intentions tetapi umumnya mereka masih akan bertahan bekerja di RS Dhuafa. Perilaku mencari informasi pekerjaan di tempat lain, dan berfikir berhenti bekerja merupakan indikator yang cukup kuat menunjukkan adanya turnover intentions pada perawat RS Dhuafa.

\section{DAFTAR PUSTAKA}

Aryanto, B. 2011. Faktor-Faktor yang Berhubungan dengan Kecendrungan Turnover Perawat di Rumah Sakit Islam "Ibnu Sina" Yarsi Sumbar Bukit Tinggi (skripsi). Padang (ID). Universitas Andalas.

Gibson, Ivancevich, Donnelly. 1996. Organisasi. Terjemahan. Jakarta (ID). Binarupa Aksara. Terjemahan dari: Organizations.
Kuswadi. 2004. Cara Mengukur Kepuasan Karyawan. Jakarta (ID). PT Elex Media Komputindo.

Mobley, W.H. 1986. Pergantian Karyawan: SebabAkibat dan Pengendaliannya. Terjemahan. Jakarta (ID). IPPM dan PT Pustaka Binaman Pressindo. Terjemahan dari: Employee Turnover: Cause, Consequences, and Control.

Nugraha, A.S. 2014. Komitmen Organisasi sebagai Mediator Pengaruh Kepuasan Kerja terhadap Turnover Intention Karyawan di Hotel Salak Bogor. Bogor (ID). Institut Pertanian Bogor.

Peraturan Menteri Kesehatan (Permenkes) Nomor 340 tahun 2010 tentang Klasifikasi Rumah Sakit Umum.

Rageb, M,A., Abd-El-Salam EM, El-Samadicy A, Farid S. 2013. Organizational Commitment, Job Satisfaction and Job Performance as a Mediator between Role Stressors and Turnover Intentions a Study from an Egyptian Cultural Perspective. The Business \& Management Review. 3 (2): 5173.

Rahmawati, M.F. 2013. Analisis Turnover Intentions Karyawan KDS Cantonese Restoran Malang. Bogor (tesis). Bogor (ID). Institut Pertanian Bogor.

Robbins, S.P., T.A. Judge. 2008. Perilaku Organisasi. Terjemahan. Jakarta (ID). Salemba Empat. Terjemahan dari: Organizational Behavior.

Sijabat, J. 2011. Pengaruh Kepuasan Kerja terhadap Komitmen Organisasi dan Keinginan untuk Pindah. Visi. 19 (3): 592-608.

Yuliasia, Y., I. Santoso dan A. Hidayat. 2012. Analisis Variabel yang Mempengaruhi Keinginan Berpindah (Turnover Intention) dengan Structural Equation Modeling (SEM) (Studi Kasus PT Wonokoyo Jaya Corporindo, Pasuruan). Jurnal Teknologi Pertanian. 13 (1): 61-66. 